\title{
Carbon stock and dynamics in a managed forest in Central Amazon
}

\section{Estoque e dinâmica de carbono em floresta manejada na Amazônia Central}

\author{
Cintia Rodrigues de Souza', Celso Paulo de Azevedo', Luiz Marcelo Brum Ross ${ }^{2}$, \\ Joaquim dos Santos $^{3}$ and Niro Higuchi ${ }^{3}$
}

\begin{abstract}
Resumo
A floresta amazônica tem estado cada vez mais em evidência nas discussões mundiais acerca de seu papel central no controle das mudanças climáticas globais, tanto pela capacidade de emitir gases do efeito estufa para a atmosfera, via queimadas ou desmatamentos, como de absorver carbono da atmosfera por meio do crescimento do povoamento. Este trabalho analisou dados de uma floresta manejada experimentalmente em 1987, em Manaus/AM. O objetivo foi estudar o estoque e dinâmica de carbono. Os inventários florestais foram realizados em 15 hectares de parcelas permanentes. As taxas médias de recrutamento foram de $4,9 \%, 4,8 \%, 3,7 \%$ e $5 \%$, para os tratamentos testemunha e exploração de $1 / 3$, $1 / 2$ e $2 / 3$, respectivamente; e as taxas médias de mortalidade foram de $3,1 \%, 6 \%, 4,8 \%$ e $6,7 \%$, para os tratamentos testemunha e exploração de 1/3, 1/2 e 2/3, respectivamente. A área basal $\left(23,1 \mathrm{~m}^{2} \mathrm{ha}^{-1}, 23,6\right.$

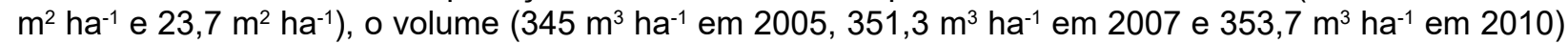
e o estoque de carbono (149,2 t ha-1 em 2005, 151,8 t ha-1 em 2007 e 152,6 t ha-1 em 2010) apresentaram aumento a cada medição realizada. Entretanto, a diferença estatística entre estes valores não foi significativa, assim, concluiu-se que a floresta manejada experimentalmente esteve em equilíbrio com a atmosfera durante o período avaliado. A comparação do estoque de carbono dos anos mensurados com o estoque pré-exploratório, em 1986, mostrou que no ano de 2010 o estoque de carbono se igualou ao conteúdo de antes da exploração florestal, significando a recuperação da floresta.
\end{abstract}

Palavras-chave: manejo florestal, mudanças climáticas, biomassa, dinâmica florestal.

\begin{abstract}
The Amazon forest has been in evidence in global discussions about their role in control of global climate change, both by the ability to emit greenhouse gases into the atmosphere via burning or thinning, how to absorb carbon from the atmosphere by through the growth of the stand. This study analyzed data from a forest managed in 1987, in Manaus/AM. This work aimed to study the carbon stock and dynamics. The forest inventories were conducted in 15 hectares of permanent plots. The average rates of recruitment were $4.9 \%, 4.8 \%, 3.7 \%$ and $5 \%$ for control treatments and logging of $1 / 3,1 / 2$ and $2 / 3$, respectively, and the average mortality rates were $3.1 \%, 6 \%, 4.8 \%$ and $6.7 \%$, for control treatments and logging of $1 / 3,1 / 2$ and $2 / 3$, respectively. The basal area $\left(23.1 \mathrm{~m}^{2} \mathrm{ha}^{-1}\right.$ in $2005,23.6 \mathrm{~m}^{2} \mathrm{ha}^{-1}$ in 2007 and $23.7 \mathrm{~m}^{2} \mathrm{ha}^{-1}$ in 2010), the volume (345 m $\mathrm{ha}^{-1}$ in 2005, $351.3 \mathrm{~m}^{3} \mathrm{ha}^{-1}$ in 2007 and $353.7 \mathrm{~m}^{3} \mathrm{ha}^{-1}$ in 2010) and the carbon content (149.2 $\mathrm{t} \mathrm{ha}^{-1}$ in $2005,151.8 \mathrm{t} \mathrm{ha}^{-1}$ in 2007 and $152.6 \mathrm{t} \mathrm{ha}^{-1}$ in 2010) increased in all measurements. However, the statistical difference between these values was not significant, so it was concluded that the forest was in equilibrium with the atmosphere during the period evaluated. A comparison of the carbon stock of the years measured with the stock pre-exploratory, in 1986, showed that in 2010 the carbon stock equaled the content before logging, meaning the forest recovery.
\end{abstract}

Keywords: forest management, climatic changes, biomass, forest dynamics.

\section{INTRODUCTION}

Tropical forests, mainly the Amazon rainforest, are important to control the global climate changes, both by the capacity to emit greenhouse effect gases into the atmosphere, via burnings or deforestation, and to absorb carbon from the atmosphere by the growth of the settlement. On one hand,

${ }^{1}$ Pesquisadora Doutora. Embrapa Amazônia Ocidental - Empresa Brasileira de Pesquisa Agropecuária, Rodovia AM 010 km 29 - Zona rural - Caixa-postal: 319 - 69011-970 - Manaus, AM, Brasil. E-mail: cintia.souza@embrapa.br; celso.azevedo@embrapa.br.

2Pesquisador Doutor. Embrapa Florestal - Empresa Brasileira de Pesquisa Agropecuária. Estrada da Riberia, Km 111 - Caixa Postal 319 - 84311-000 - Colombo, PR, Brasil. E-mail: marcelo.rossi@embrapa.br.

3Pesquisador Doutor. INPA - Instituto Nacional de Pesquisas da Amazônia / Coordenação de Pesquisas em Silvicultura Tropical. Av. Andre Araújo, 2936 - Caixa Postal: 478 - 69011-970 - Manaus, AM, Brasil. E-mail: joca@inpa.gov.br; niro@inpa.gov.br.

Sci. For., Piracicaba, v. 46, n. 119, p. 427-436, set. 2018 DOI: dx.doi.org/10.18671/scifor.v46n119.10 
the forest can act as a sink, because trees absorb carbon during photosynthesis and store the excess in the form of biomass (HIGUCHI et al., 2004). Bellassen and Luyssaert (2014) claim that in recent decades, the forests have absorbed about $30 \%$ of the annual $\mathrm{CO}_{2}$ emissions, the equivalent to $2 \mathrm{Pg}$ of carbon per year.

However, forests can also be carbon sources due to the reduction in their productivity and increase in mortality rates arising from the increase in temperature and the severity of the drought (CLARK, 2004, HIGUCHI et al., 2011), or due to deforestation and burnings, significant sources of greenhouse gases to the atmosphere (FEARNSIDE, 1997; Houghton et al., 2000). The disclosure of the second inventory of greenhouse gases emission of Brazil (SEEG Brasil, 2017) showed that deforestation and agricultural activities are responsible for the larger share of carbon dioxide emissions, with net emissions in the sector representing 68\% of the total emissions of this gas in 2015 and about $20 \%$ of global emissions of greenhouse gases. According to Brienen et al. (2015), the Amazon rainforest is one of the largest reservoirs of terrestrial carbon, with stock of 150 to $200 \mathrm{Pg} \mathrm{C}$ in living biomass and soils. To properly manage this immense natural reservoir of carbon will certainly greatly contribute in the effort to reduce emissions of carbon into the atmosphere in Brazil.

In 2014, IPCC disclosed in its report on global warming that practices in forest management are important to account for both mitigation and adaptation. The possible practices and impacts are: management of forests for sustainable timber production including extending rotation cycles, reducing damage to remaining trees, reducing logging waste, implementing soil conservation practices, and using wood in a more efficient way, sustainable extortion of wood energy (IPCC, 2014).

The sustainable forest management offers two possibilities for mitigating the effects of global warming: storing carbon in wood products, while the managed forest grows again (capturing more carbon from the atmosphere), and through changes in logging practices, which can significantly reduce the damage to the remaining forest and the consequent carbon emission (FEARNSIDE, 1995).

This study aims to evaluate the contribution of the sustainable forest management to the carbon sequestration from the atmosphere, through the quantification of carbon stock and dynamics in Central Amazon.

\section{MATERIAL AND METHODS}

\section{Experimental site}

The study was performed at Experimental Station of Tropical Forestry of the National Institute for Amazon Research, INPA, in the municipality of Manaus (AM), between the coordinates $2^{\circ} 37^{\prime}$ to $2^{\circ} 38^{\prime} \mathrm{S}$ and $60^{\circ} 09^{\prime}$ and $60^{\circ} 11^{\prime} \mathrm{W}$.

The forest cover is typical of tropical humid dense forest of terra firme, characterized as one of the most heterogeneous of the Amazon. By Köppen classification, the climate of the region is of the "Amw" type, tropical rainy, with high temperature, rainfall, and relative humidity. The mean annual temperature is $26.7^{\circ} \mathrm{C}$ and the mean annual relative humidity is $83 \%$. Annual precipitation reaches $2500 \mathrm{~mm}$, being concentrated mainly in the rainy season, between the months of December and May. The so-called dry season occurs between June and November.

The most representative soil of the region is the yellow latosol, which occupies the surface of plateaus, with the presence of mean and porous horizon, situated between two little porous horizons (CHAUVEL, 1982).

\section{Experimental design}

The experimental design was in randomized blocks, being four blocks of 24 ha ( $400 \times 600 \mathrm{~m}$ ). Each block contained six treatments of 4 ha $(200 \times 200 \mathrm{~m})$, corresponding to the different silvicultural treatments applied in 1987, when logging was done. The logging treatments used were:

- Treatment 0: control, without logging;

- Treatment 1: removal of $1 / 3$ of the basal area;

- Treatment 2: removal of $1 / 2$ of the basal area;

- Treatment 3: removal of $2 / 3$ of the basal area. 
The permanent plots of 1 ha each $(100 \times 100 \mathrm{~m})$ were installed in the center of the treatments, canceling possible edge effects. Selective exploitation treatments were applied in 1987. The forest dynamics data used were those of the years 2005, 2007, 2009, and 2010, to conform to forest inventories conducted in the same years, in non-managed areas.

All individual trees with diameter at breast height (DBH) equal or superior to $10 \mathrm{~cm}$ were measured. With the collected data, we calculated the rates of recruitment and mortality, the periodic annual increments in $\mathrm{DBH}\left(\mathrm{PAI}_{\mathrm{DBH}^{\prime}} \mathrm{cm}\right.$ year $\left.{ }^{-1}\right)$, basal area $\left(\mathrm{PAI}_{\mathrm{G}^{\prime}} \mathrm{m}^{2} \mathrm{ha}^{-1}\right.$ year-1 $\left.{ }^{-1}\right)$, volume $\left(\mathrm{PAI}_{\mathrm{V}^{\prime}} \mathrm{m}^{3}\right.$ ha $^{-1}$ year $\left.^{-1}\right)$, and carbon stock $\left(\mathrm{PAI}_{\mathrm{C}^{\prime}} \mathrm{t} \mathrm{C} \mathrm{ha-}^{-1}\right.$ year $\left.^{-1}\right)$.

The individual volume $\left(\mathrm{v}_{\mathrm{i}}\right)$ was obtained by using the equation adjusted by Lima (2010) for the central region of Manaus. Volume per hectare (plot) was obtained by the sum of the individual volumes of each tree.

$$
v_{i}=0.001176 *(D B H)^{1.99868} \quad\left(R^{2}=0.89 \text { and uncertainty }=4.0 \%\right)
$$

In which:

$\mathrm{v}_{\mathrm{i}}=$ trade volume with bark in $\mathrm{m}^{3}$;

$\mathrm{DBH}=$ diameter at breast height in $\mathrm{cm}$;

For the determination of the carbon content, we used the equations proposed by Silva (2007).

$$
\begin{gathered}
F B_{a b g}=2.2737 \times D B H^{1.9156} \quad\left(R^{2}=0.85\right) \\
F B_{t o t}=2.7179 \times D B H^{1.8774} \quad\left(R^{2}=0.94\right) \\
D B_{a b g}=\left(F B_{a b g}\right) \times 0.592 \\
D B_{t o t}=\left(F B_{t o t}\right) \times 0.584 \\
C_{a b g}=\left(D B_{a b s}\right) \times 0.485 \\
C_{t o t}=\left(D B_{t o t}\right) \times 0.485
\end{gathered}
$$

In which:

$\mathrm{FB}_{\mathrm{abg}}=$ above-ground level fresh biomass;

$\mathrm{B}_{\text {tot }}=$ total fresh biomass (above ground level + thick roots);

$\mathrm{DB}_{\mathrm{abg}}=$ above-ground level dry biomass;

$\mathrm{DB}_{\text {tot }}=$ total dry biomass (above ground level + thick roots);

$\mathrm{C}_{\mathrm{abg}}=$ vegetation carbon above-ground level;

$\mathrm{C}_{\text {tot }}=$ total carbon (above ground level + thick roots).

The statistical analyzes were performed to assess if the increases in diameter, basal area, volume and carbon stock, mortality, recruitment and annual periodic increments (in diameter, basal area, volume and carbon stock) were influenced by different treatments over time. For this we used the analysis of variance with repeated measures in time. The treatments were the years of measurement.

To evaluate the forest recovery after the experimental management, an analysis of variance was made, to compare the forest carbon stocks before and after the logging, followed by a multiple comparison procedure, Dunnett's test, taking as a control factor the carbon stock in the forest in 1986.

All analyzes were performed using the statistical software SAS ${ }^{\circledR} 9.2$.

\section{RESULTS AND DISCUSSION}

In the evaluated forest area, were identified in 2010 7,097 individuals from 284 species belonging to 50 botanical families. Regarding carbon stock, the most representative families were Lecythidaceae, Fabaceae, Sapotaceae, Euphorbiaceae, Apocynaceae, Burseraceae, and Lauraceae, respectively. These data are detailed in Table 1. 
Souza et al. - Carbon stock and dynamics in a managed forest in Central Amazon

Table 1. Carbon stocks (in 2005, 2007 and 2010) and increments for the most representative families of the managed forest.

Tabela 1. Estoques e incrementos de carbono (em 2005, 2007 e 2010) para as famílias mais representativas da floresta manejada.

\begin{tabular}{|c|c|c|c|c|c|}
\hline Family & $\begin{array}{l}\text { C Stock } \\
\left.(\mathrm{t} \mathrm{ha})^{-1}\right)\end{array}$ & $\begin{array}{l}\text { C Stofk } \\
(\mathrm{t} \mathrm{ha-1})\end{array}$ & $\begin{array}{l}\text { C Stpok } \\
(\mathrm{t} \mathrm{ha-1})\end{array}$ & $\begin{array}{c}\text { C Increment } \\
2005-2007 \\
\left(\mathrm{t} \mathrm{ha} \text { hear }^{-1}\right)\end{array}$ & $\begin{array}{c}\text { C Increment } \\
2007-2010 \\
\left(\mathrm{t} \mathrm{ha-1} \text { year }^{-1}\right)\end{array}$ \\
\hline Lecythidaceae & 300.76 & 305.21 & 311.78 & 2.22 & 2.19 \\
\hline Fabaceae & 274.97 & 279.17 & 290.65 & 2.09 & 3.83 \\
\hline Sapotaceae & 194.57 & 194.22 & 191.87 & -0.17 & -0.78 \\
\hline Euphorbiaceae & 125.47 & 128.81 & 130.06 & 1.67 & 0.41 \\
\hline Apocynaceae & 80.13 & 79.38 & 80.62 & 0.37 & 0.41 \\
\hline Burseraceae & 76.40 & 77.74 & 80.37 & 0.67 & 0.87 \\
\hline Lauraceae & 69.88 & 72.22 & 72.57 & 1.17 & 0.12 \\
\hline
\end{tabular}

The species with the highest carbon stocks were Eschweilera coriacea (DC) S.A. Mori (76.7 tons of carbon in 2010), Couratari alta (40.8 t C), Protium hebetatum (37.6 t C), Micrandropsis scleroxylon $(32.3 \mathrm{t} \mathrm{C})$ and Inga obidensis $(31.2 \mathrm{t} \mathrm{C})$. There was a predominance of pioneer species. Besides Inga obidensis, the following species also showed significant values: Croton lanjouwensis (29.4 t C), Cecropia sciadophylla (14.3 t C) and Vismia sp. (14.1 t C).

Regarding the floristic composition, other authors obtained similar results in the same field of study, such as Jardim and Hosokawa (1986) and Carneiro (2004), which highlighted that the Sapotaceae family was the richest in number of species; however, the botanical family with the highest number of individuals was Lecythidaceae. In this study, the species that showed higher carbon stocks were: Eschweilera coriacea (D.C.) S.A. Mori (matamatá amarelo, with $76.7 \mathrm{t}$ of carbon in 2010), Couratari alta Kunth. (tauari, with 40.8 t C), Protium hebetatum D.C. Daly (breu vermelho, with 37.6 t C), Micrandropsis scleroxylon (W.A. Rodrigues) W.A. Rodrigues (piãozinho, with 32.3 t C) and Inga obidensis Ducke (ingá vermelho, with 31.2 t C).

We evaluated the recruitment and mortality rates for each applied treatment. Between 2005 and 2010, the recruitment and mortality rates showed a great variation, with no clear definition of a behavioral pattern. In most cases, the recruitment rates observed were higher than the mortality rates in the analyzed periods. The results regarding the annual recruitment and mortality rates can be found in Table 2 .

Table 2. Annual recruitment and mortality rates (\%) for the periods $2005 / 2007$ and $2007 / 2010$.

Tabela 2. Taxas de recrutamento e mortalidade anuais (\%) para os períodos 2005/2007 e 2007/2010.

\begin{tabular}{|c|c|c|c|c|}
\hline \multirow{2}{*}{ Treatment } & Recruitment (\%) & Mortality (\%) & Recruitment (\%) & Mortality (\%) \\
\hline & \multicolumn{2}{|c|}{$2005 / 2007$} & \multicolumn{2}{|c|}{$2007 / 2010$} \\
\hline 0 & 4.65 & 2.46 & 5.17 & 3.75 \\
\hline 1 & 3.96 & 3.98 & 5.67 & 8.18 \\
\hline 2 & 3.77 & 2.81 & 3.69 & 6.91 \\
\hline 3 & 4.71 & 4.36 & 5.29 & 9.13 \\
\hline Mean & 4.14 & 3.72 & 4.88 & 8.07 \\
\hline
\end{tabular}

Fontes (2012) claims that deaths of trees are more frequent in the rainy season, indicating a strong influence of the rainfall on tree mortality (the storms were responsible for $45 \%$ of deaths). Higuchi et al. (2011) and Negrón-Juarez et al. (2010) also concluded that the combination between rainfall and winds is responsible for most of the tree mortality in the Amazon region, supplanting the hydric stress caused by drought events.

In the Tapajós National Forest, Silva et al. (1995) obtained recruitment rate of 3.1\% per year, eleven years after heavy exploitation and without silvicultural treatments. In the forests of Vitória do Jari/AP, recruitment values were significantly lower. Azevedo et al. (2008), analyzing the effect of different levels of exploitation on the dynamics of the remnant forest, found the following mean values of total recruitment: $1.68 \%$ for light exploitation treatments, $2.15 \%$ for the average, and $2.41 \%$ for the heavy ones, with global mean of $2.08 \%$ per year, after twenty years of monitoring 
post-exploitation. As for mortality, Kohler et al. (2001) state that, normally, the mean rates in undisturbed tropical forests vary between $1 \%$ and $3.2 \%$ per year, values close to those found in this study. In studies in the Brazilian Amazon forest, Alder and Silva (2000) found mortality rates ranging between $0.5 \%$ and $4.1 \%$. Several authors found lower mortality rates than those recorded in this study. In a study conducted by Colpini et al. (2010), the mortality rate of a forest in Mato Grosso was $0.78 \%$. Higuchi et al. (2004) found mortality of $0.7 \%$ in a forest in the region of Manaus (AM), between 1986 and 2000. Silva et al. (1995) studied a forest in the Amazon 13 years after logging, and achieved annual mortality rate of $2.2 \%$ for all species and $1.3 \%$ for commercial species.

The difference between the applied treatments was also evaluated regarding carbon sequestration. Figure 1 graphically shows the evolution in the carbon stock for the studied treatments.

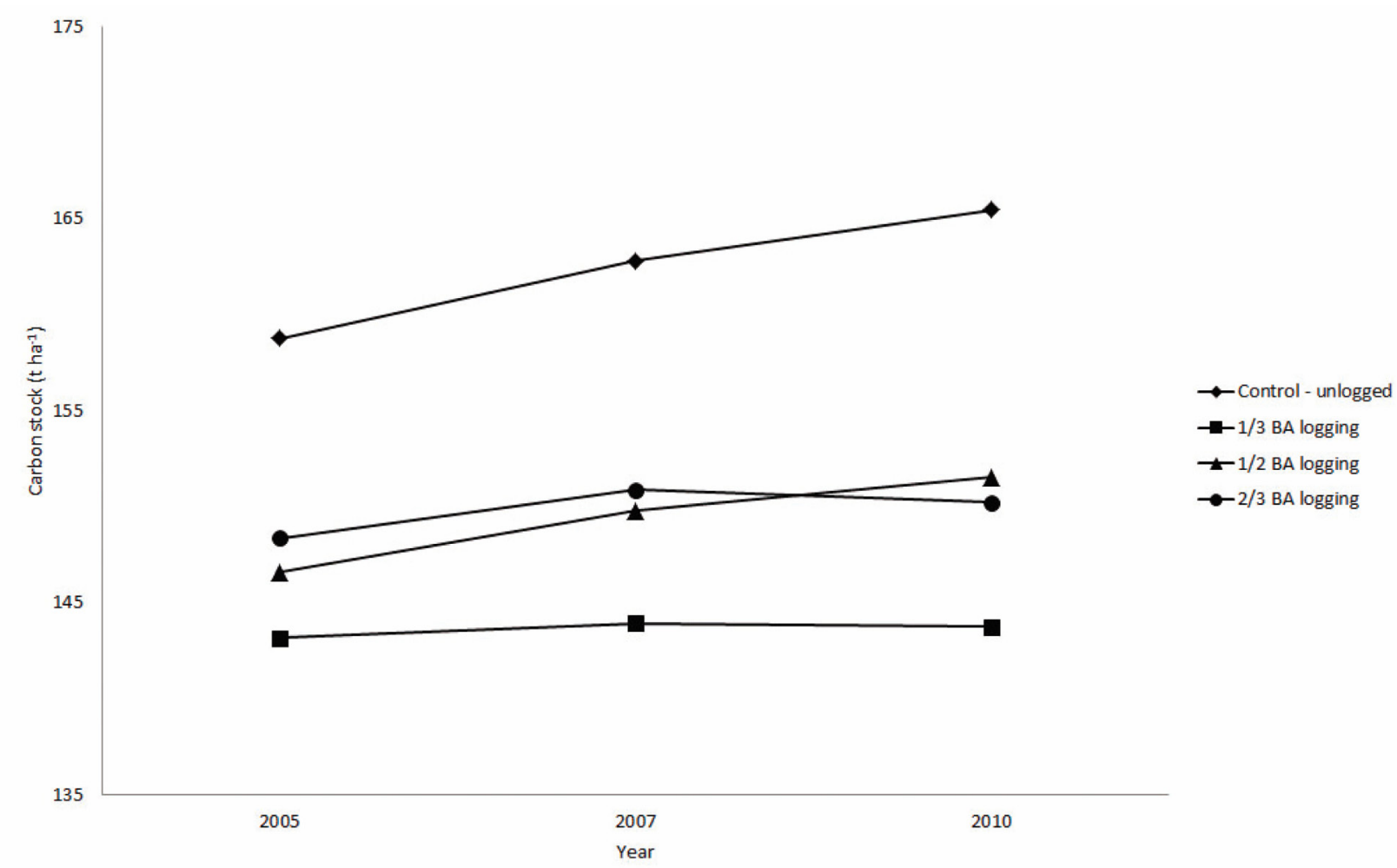

Figure 1. Carbon dynamics (annual mean) of trees with $\mathrm{DBH} \geq 10 \mathrm{~cm}$ in Manaus region in the period between 2005 and 2010.

Figura 1. Dinâmica do carbono (medias anuais) de árvores com DAP $\geq 10 \mathrm{~cm}$ na região de Manaus no período entre 2005 e 2010.

Observing Figure 1, we notice that the unlogged area presented the greatest carbon stocks throughout the period evaluated. In addition, the amount of carbon is increasing over time. Concerning logging treatments, the treatment 2 (removal of $1 / 2$ of the exploitable basal area), was the only one that has shown increase in the amount of carbon. This and the logging of $1 / 3$ of the basal area showed a reduction in values between the 2007 and 2010 measurements. By way of comparison, in 1986, one year before the experimental exploitation held in the area, the mean stock of carbon in the area was of $167.5 \mathrm{t} \mathrm{ha}^{-1}$, i.e., a value rather close to the stock of the unexplored area in the year of 2010. Table 3 shows the mean values of DBH, basal area, volume, and carbon stock for the area experimentally managed. We performed analysis of variance of measures repeated in time, in which all the variables analyzed significantly varied over time $(\mathrm{p}<0.0001, \mathrm{p}=0.0014, \mathrm{p}=0.0014$, and $\mathrm{p}=0.0077$, for $\mathrm{DBH}$, basal area, volume, and carbon stock, respectively). When considering the interaction between time and treatment, i.e., the evaluation of whether the logging treatments influenced these variables, only the DBH showed a statistically significant difference $(\mathrm{p}=0.0003)$. Thus, we could say that, statistically, the applied treatments only exerted significant influence on the behavior of DBH with the passage of time. 
Table 3. Mean values (mean \pm standard deviation) of DBH $(\mathrm{cm})$, basal area $\left(\mathrm{m}^{2} \mathrm{ha}^{-1}\right)$, volume $\left(\mathrm{m}^{3}\right.$ ha-1), and total carbon stock ( $\mathrm{t} \mathrm{ha}^{-1}$ ) in the years 2005, 2007, and 2010 on each evaluated logging treatment (for individuals with $\mathrm{DBH} \geq 10 \mathrm{~cm}$ ).

Tabela 3. Valores médios (média \pm desvio padrão) de DAP $(\mathrm{cm})$, área basal $\left(\mathrm{m}^{2} \mathrm{ha}^{-1}\right)$, volume $\left(\mathrm{m}^{3} \mathrm{ha}^{-1}\right)$ e estoque de carbono total ( $\mathrm{t} \mathrm{ha}^{-1}$ ) para os anos de 2005, 2007 e 2010, para cada tratamento avaliado (para indivíduos com DAP $\geq 10 \mathrm{~cm}$ ).

\begin{tabular}{|c|c|c|c|c|c|}
\hline Year & Treatments & $\mathrm{DBH}(\mathrm{cm})$ & BA $\left(m^{2} h a^{-1}\right)$ & $V\left(m^{3} h a^{-1}\right)$ & C (t ha-1) \\
\hline \multirow{5}{*}{2005} & 0 & 21.0 & $24.78 \pm 2.26$ & $369.28 \pm 33.75$ & $158.7 \pm 13.3$ \\
\hline & 1 & 21.0 & $22.2 \pm 3.2$ & $331.4 \pm 48.2$ & $143.2 \pm 18.8$ \\
\hline & 2 & 21.0 & $22.7 \pm 2.6$ & $338.7 \pm 38.7$ & $146.6 \pm 16.2$ \\
\hline & 3 & 20.3 & $22.8 \pm 0.5$ & $340.8 \pm 8.1$ & $148.4 \pm 2.7$ \\
\hline & Mean & 20.4 & $23.1 \pm 1.1$ & $345.0 \pm 16.7$ & $149.2 \pm 6.7$ \\
\hline \multirow{5}{*}{2007} & 0 & 20.4 & $25.39 \pm 2.37$ & $378.46 \pm 35.25$ & $162.6 \pm 13.8$ \\
\hline & 1 & 20.6 & $22.3 \pm 3.3$ & $333.3 \pm 49.1$ & $143.9 \pm 19.1$ \\
\hline & 2 & 21.1 & $23.2 \pm 2.4$ & $346.5 \pm 35.9$ & $149.8 \pm 15.1$ \\
\hline & 3 & 21.3 & $23.2 \pm 0.4$ & $346.8 \pm 5.5$ & $150.8 \pm 1.5$ \\
\hline & Mean & 20.5 & $23.6 \pm 1.3$ & $351.3 \pm 19.2$ & $151.8 \pm 7.8$ \\
\hline \multirow{5}{*}{2010} & 0 & 21.7 & $25.74 \pm 2.19$ & $383.58 \pm 32.69$ & $164.8 \pm 12.9$ \\
\hline & 1 & 19.8 & $22.4 \pm 3.6$ & $333.5 \pm 53.9$ & $143.7 \pm 21.1$ \\
\hline & 2 & 19.9 & $23.6 \pm 2.6$ & $351.7 \pm 38.7$ & $151.5 \pm 16.1$ \\
\hline & 3 & 20.4 & $23.2 \pm 0.9$ & $345.8 \pm 5.5$ & $150.2 \pm 5.5$ \\
\hline & Mean & 20.9 & $23.7 \pm 1.4$ & $353.7 \pm 21.3$ & $152.6 \pm 8.8$ \\
\hline \multicolumn{2}{|l|}{ Mean } & & 23.5 & 350.0 & 151.2 \\
\hline \multicolumn{2}{|c|}{ Standard deviation } & & 1.2 & 17.7 & 7.2 \\
\hline \multicolumn{2}{|c|}{ Confidence interval (95\%) } & & 1.4 & 20.5 & 8.4 \\
\hline \multicolumn{2}{|c|}{ Uncertainty } & & 5.8 & 5.8 & 5.5 \\
\hline
\end{tabular}

Table 4 presents the periodic annual increments in DBH, basal area, volume, and carbon stock for the exploitation treatments evaluated. We notice that most of the periodic annual increments showed positive values in the evaluated periods. Only for the interval between 2007 and 2010, the periodic annual increment in carbon presented negative values for the $1 / 3$ and 2/3 exploitation treatments of the basal area, which means that the forest subjected to these treatments emitted a greater amount of carbon into the atmosphere than the amount absorbed. This fact may be related to the greater mortality that occurred during this period for these treatments, as we can observe in Table 2.

Table 4. Periodic annual increments (PAI) in DBH $(\mathrm{cm}$ year-1 $)$, basal area $\left(\mathrm{m}^{2} \mathrm{ha}^{-1}\right.$ year-1 $)$, volume $\left(\mathrm{m}^{3} \mathrm{ha}^{-1}\right.$ year-1), and carbon stock ( $\mathrm{t} \mathrm{ha}^{-1}$ year-1) for for individuals with $\mathrm{DBH} \geq 10 \mathrm{~cm}$.

Tabela 4. Incrementos periódicos anuais (IPA) in DAP $(\mathrm{cm}$ ano-1 $)$, área basal $\left(\mathrm{m}^{2} \mathrm{ha}^{-1} \mathrm{ano}^{-1}\right)$, volume $\left(\mathrm{m}^{3} \mathrm{ha}^{-1} \mathrm{ano}^{-1}\right)$, e estoque de carbono ( $\mathrm{t} \mathrm{ha}^{-1} \mathrm{ano}^{-1}$ ) para todos os indivíduos com $\mathrm{DAP} \geq 10 \mathrm{~cm}$.

\begin{tabular}{lcc|cc|cc|cc}
\hline \multirow{2}{*}{ Treat. } & \multicolumn{2}{c|}{ PAI DBH $\left(\mathbf{c m ~ y e a r}{ }^{-1}\right)$} & \multicolumn{2}{c|}{ PAl BA $\left(\mathbf{m}^{\mathbf{2}}\right.$ ha $^{-1}$ year $\left.^{-1}\right)$} & \multicolumn{2}{c|}{ PAl V $\left(\mathbf{m}^{\mathbf{3}}\right.$ ha $^{-1}$ year $\left.^{-1}\right)$} & \multicolumn{2}{c}{ PAl C $\left(\mathrm{t} \mathrm{ha}^{-1}\right.$ year $\left.^{-1}\right)$} \\
\cline { 2 - 10 } & $\mathbf{2 0 0 5 - 2 0 0 7}$ & $\mathbf{2 0 0 7 - 2 0 1 0}$ & $\mathbf{2 0 0 5 - 2 0 0 7}$ & $\mathbf{2 0 0 7 - 2 0 1 0}$ & $\mathbf{2 0 0 5 - 2 0 0 7}$ & $\mathbf{2 0 0 7 - 2 0 1 0}$ & $\mathbf{2 0 0 5 - 2 0 0 7}$ & $\mathbf{2 0 0 7 - 2 0 1 0}$ \\
\hline 0 & 0.20 & 0.16 & 0.362 & 0.288 & 3.805 & 2.095 & 1.56 & 0.89 \\
1 & 0.23 & 0.23 & 0.065 & 0.013 & 0.970 & 0.187 & 0.30 & -0.06 \\
2 & 0.23 & 0.22 & 0.261 & 0.116 & 3.894 & 1.727 & 1.24 & 0.58 \\
3 & 0.29 & 0.25 & 0.191 & 0.053 & 2.848 & 0.793 & 0.96 & -0.22 \\
Mean & 0.25 & 0.23 & 0.172 & 0.060 & 2.571 & 0.902 & 0.833 & 0.10 \\
\hline
\end{tabular}

These results of the periodic annual increments are lower than those found in the literature. Silva et al. (1995) found a growth rate in diameter of $0.3 \mathrm{~cm}_{\text {year }}{ }^{-1}$, thirteen years after logging, in the Tapajós National Forest. Silva (2004), in Paragominas/PA, compared the growth rates in two situations: in the forest where exploitation based on sustainable forest management occurred, the growth rate was $0.5 \mathrm{~cm}_{\text {year }}{ }^{-1}$; on the other hand, the rate was $0.3 \mathrm{~cm}$ year ${ }^{-1}$ in the areas where conventional exploitation occurred, seven years after the exploitation. When comparing the treatments, the one which showed the highest increment in the studied period was the one of heavy intensity, with 75\% of the basal area exploited. De Graaf (1986) found a rate of $0.4 \mathrm{~cm}_{\text {year }}{ }^{-1}$, in Suriname, nine years after logging. Oliveira and Braz (2006), studying an area of a forest managed in Pedro Peixoto (AC), 
found higher increment values in diameter, as expected in relation to a non-managed area. The values ranged from $2 \mathrm{~cm}_{\text {year }}{ }^{-1}$, for pioneer species, to $0.1 \mathrm{~cm}_{\text {year }}{ }^{-1}$, for some brushwood species.

The same happened with the increments in volume. Research conducted by Higuchi et al. (1997), in the same region of study, describe the growth and the development of a forest, ten years after the selective exploitation of wood. The results showed that the increments in trade volume with bark were: $5.57 \mathrm{~m}^{3}$ ha $^{-1}$ year-1 for exploitation of light intensity (DBH $\geq 55 \mathrm{~cm}$ ); $4.45 \mathrm{~m}^{3} \mathrm{ha}^{-1}$ year $^{-1}$ for mean exploitation (DBH $\geq 50 \mathrm{~cm}$ ); and $5.75 \mathrm{~m}^{3} \mathrm{ha}^{-1}$ year $^{-1}$ for heavy exploitation (DBH $\geq 40$ $\mathrm{cm})$. In the unmanaged area, the PAI was $2.82 \mathrm{~m}^{3} \mathrm{ha}^{-1}$ year ${ }^{-1}$. As well as in the study of Silva et al. (1996), for trade species (including only species locally and nationally commercialized and with $\mathrm{DBH} \geq 50 \mathrm{~cm}$ ), the increase was $1 \mathrm{~m}^{3} \mathrm{ha}^{-1}$ year $^{-1}$. In the region of Santarém/PA, Silva et al. (1996) also obtained higher increment values, 7 and 13 years after exploitation. In these areas, the periodic annual increments in volume ranged from $1.6 \mathrm{~m}^{3} \mathrm{ha}^{-1}$ year ${ }^{-1}$ in primary forest to $4.8 \mathrm{~m}^{3} \mathrm{ha}^{-1}$ year ${ }^{-1}$ in managed forest. A possible explanation for these results is that Silva et al. (1996) and Higuchi et al. (1997) evaluated the forests about a decade after the exploitation, when they were showing higher growth due to the intervention carried out. The forests studied in the present study were evaluated 23 years after the management, when a balance in its growth process is expected, approaching the rates presented by primary forest.

Some studies conducted by other authors aim to elucidate the influence (positive or negative) that forest management may have regarding carbon sequestration from the atmosphere. Schmid et al. (2006) state that forest management (with different intensities of thinning, number of years of the cycle, silvicultural treatments etc.) influences a particular forest to be considered a carbon source or sink. Seidl et al. (2007) evaluated the correlation between carbon sequestration and the sustainable wood production in a multiple-use forest in Austria and concluded that carbon sequestration from atmosphere is higher in sustainably managed forests than in non-managed forests. The estimated costs indicate that the carbon sequestration through forest management is an efficient mean to reduce atmospheric $\mathrm{CO}_{2}$. The authors emphasize the importance of developing sustainable management strategies consistent with the multiple uses of forests.

To evaluate the forest recovery process after the experimental management, we made a comparison between the carbon contents of the forest before logging (occurred in 1987) and the stocks in the years in which measurements occurred $(2005,2007$, and 2010). By Figure 2 we may note that the forest is very close to reach the existing stocks prior to exploitation. To confirm this information, an analysis of variance was performed, followed by post hoc Dunnett's test.

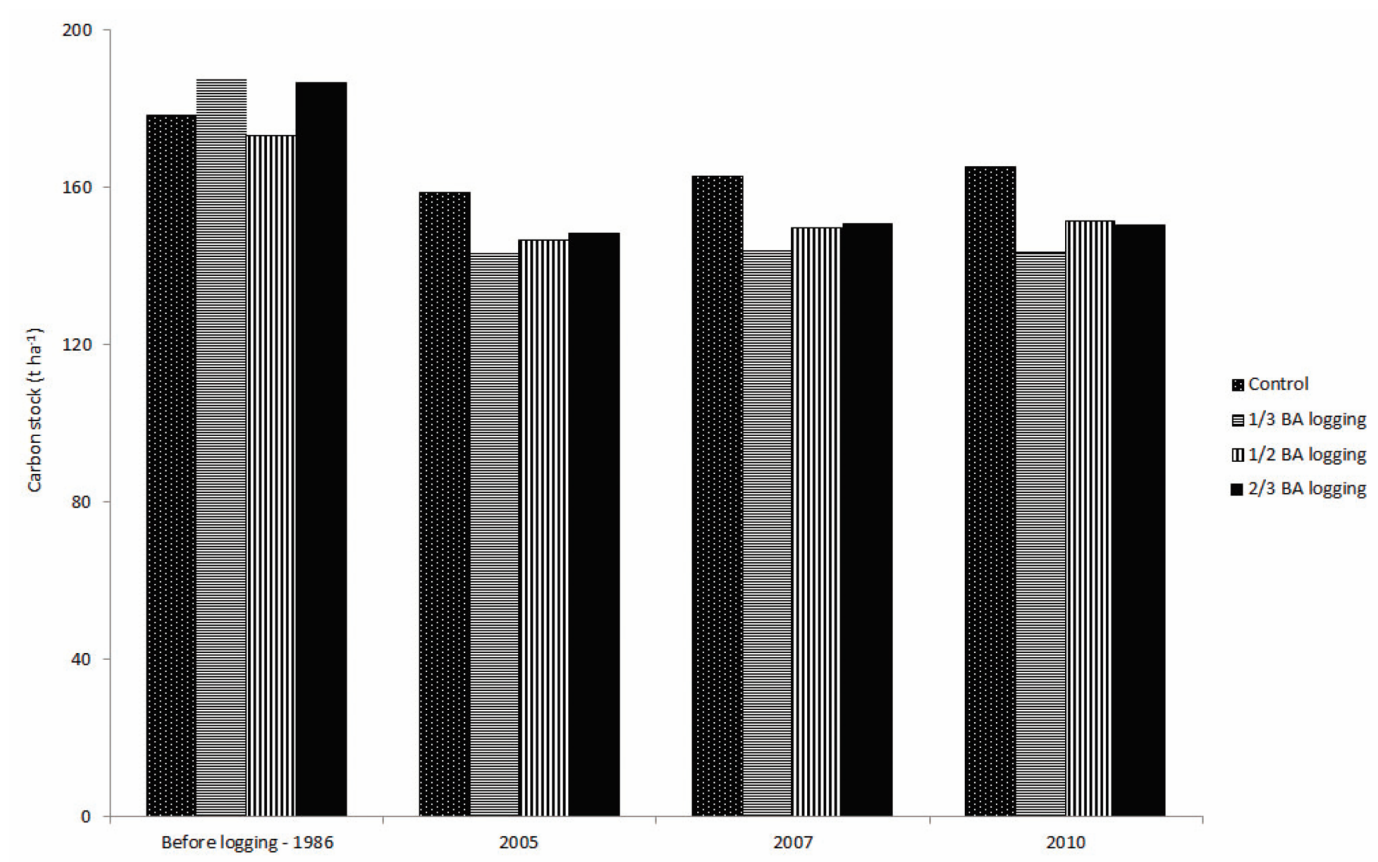

Figure 2. Forest carbon stocks in 1986 (pre-logging) and in the years 2005, 2007, and 2010, in forest experimentally managed.

Figura 2. Estoques de carbono florestal em 1986 (antes da exploração) e nos anos de 2005, 2007 e 2010, na floresta manejada experimentalmente. 
The differences in mean values between treatment groups are greater than what would be expected by chance, thus, there is statistically significant difference $(\mathrm{p}=0.022)$. To isolate the group that differs from the others, Dunnett's test was carried out, considering it as a factor of control the carbon stock in the forest in 1986 (pre-logging).

Comparing to the carbon stock contained in the forest before the experimental logging, stocks of 2005 and 2007 were significantly different. On the other hand, in 2010, the carbon stock did not show a statistically significant difference, i.e., the carbon content equaled the quantities present in the forest before the exploitation of this area, being recovered 23 years after exploitation, regarding carbon stocks. Nevertheless, we cannot say that the forest area is ready to be managed again, mainly because of its floristic composition, where in the managed area there is still greater predominance of pioneering species, when compared with the non-managed area.

\section{CONCLUSION}

Regarding the effect of forest management on carbon sequestration, we concluded that there was no difference between the logging treatments employed. After 23 years of application of the treatments, the carbon stocks in the area equaled the stocks existing before logging, indicating forest recovery in terms of biomass. Nevertheless, it cannot be said that the area is ready to be managed again, mainly due to the high number of pioneer species still existing in the area.

\section{REFERENCES}

ALDER, D.; SILVA, J. N. M. An empirical cohort model for management of Terra Firme forests in the Brazilian Amazon. Forest Ecology and Management, Amsterdan, v. 130, n. 1-3, p. 141-157, 2000.

AZEVEDO, C. P.; SANQUETTA, C. R.; SILVA, J. N. M.; MACHADO, S. A. Efeito de diferentes níveis de exploração e de tratamentos silviculturais sobre a dinâmica da floresta remanescente. Floresta, Curitiba, v. 38, n. 2, p. 277-293, 2008.

BELLASSEN, V.; LUYSSAERT, S. Managing forests in uncertain times. Nature, London, v. 506, n. 7487, p. 153155, 2014.

BRIENEN, R. J. W.; PHILLIPS, O. L.; FELDPAUSCH, T. R.; GLOOR, E.; BAKER, T. R.; LLOYD, J. Long-term decline of the Amazon carbon sink. Nature v. 519, p. 344-347, 2015.

CARNEIRO, V. M. C. Composição florística e análise estrutural na floresta primária de terra firme da bacia do rio Cuieiras, Manaus-AM. 2004. 83 p. Dissertação (Mestrado em Ciências Biológicas) - Instituto Nacional de Pesquisas da Amazônia, Universidade Federal do Amazonas, Manaus, 2004.

CHAUVEL, A. Os latossolos amarelos, álicos, argilosos, dentro dos ecossistemas das bacias experimentais do INPA e da região vizinha. Acta Amazonica, Manaus, v. 12, n. 3, p. 47- 60, 1982.

CLARK, D. A. Sources or sinks? The responses of tropical forests to current and future climate and atmospheric composition. Philosophical Transactions of the Royal Society of London B, London, v. 359, n. 1443, p. 477-491, 2004.

COLPINI, C.; SILVA, V. S. M.; SOARES, T. S. Incremento, ingresso e mortalidade em uma floresta de contato ombrófila aberta/estacional em Marcelândia, Mato Grosso. Acta Amazonica, Manaus, v. 40, n. 3, p. 549-556, 2010.

DE GRAAF, N. R. A silvicultural system for natural regeneration of tropical rain forest in Suriname. Wageningen: Agricultural University, 1986. 250 p. 
FEARNSIDE, P. M. Global warming response options in Brazil's forest sector: Comparison of project-level costs and benefits. Biomass and Bioenergy, Oxford, v. 8, n. 5, p. 309-322, 1995.

FONTES, C. G. Revelando as causas e a distribuição temporal da mortalidade arbórea em uma floresta de terra-firme na Amazônia Central. 2012. 63 p. Dissertação (Mestrado em Ciências Florestais) - Instituto Nacional de Pesquisas da Amazônia, Universidade Federal do Amazonas, Manaus, 2012.

HIGUCHI, N.; SANTOS, J.; LIMA, A. J. N.; HIGUCHI, F. G.; CHAMBERS, J. Q. A floresta amazônica e a água da chuva. Floresta, Curitiba, v. 41, n. 3, p. 427-434, 2011.

HIGUCHI, N.; CHAMBERS, J.; SANTOS, J.; RIBEIRO, R. J.; PINTO, A. C. M.; SILVA, R. P.; ROCHA, R. M.; TRIBUZY, E. S. Dinâmica e balanço do carbono da vegetação primária da Amazônia central. Floresta, Curitiba, v. 34, n. 3, p. 295-304, 2004.

HIGUCHI. N.; SANTOS. J. DOS; RIBEIRO. R. J.; FREITAS, J. V.; VIEIRA, G.; CÖIC, A.; MINETTE, L. J. Crescimento e Incremento de uma Floresta Amazônica de Terra firme Manejada Experimentalmente. In: INPA/DFID (Ed.). Biomassa e nutrientes florestais, Relatório final do projeto BIONTE. Manaus: INPA, 1997. p. 89-132.

HOUGHTON, R. A.; SKOLE, D. L.; NOBRE, C. A.; HACKLER, J. L.; LAWRENCE, K. T.; CHOMENTOWSKI, W. H. Annual fluxes of carbon from deforestation and regrowth in the Brazilian Amazon. Nature, London, v. 403, p. 301-304, 2000.

IPCC. INTERGOVERNMENTAL PANEL ON CLIMATE CHANGE. Contribución del Grupo de Trabajo III al Cuarto Informe de Evaluación del Grupo Intergubernamental de Expertos sobre Cambio Climático. Resumen Técnico, 2007. Disponível em < http://www.ipcc.ch >. Acesso em 06 dez. 2007.

JARDIM, F. C. S.; HOSOKAWA, R. T. Estrutura da floresta equatorial úmida da Estação Experimental de Silvicultura Tropical do INPA. Acta Amazonica, Manaus, v. 16/17, p. 411- 508, 1986.

KOHLER, P.; DITZER, T.; ONG, R. C.; HUTH, A. Comparison of measured and modelled growth on permanent plots in Sabahs rain forests. Forest Ecology and Management, Amsterdan, v. 144, n. 1-3, p. 101-111, 2001.

LIMA, A. J. N. L. Avaliação de um sistema de Inventário Florestal Contínuo em áreas manejadas e não manejadas do Estado do Amazonas (AM). 2010. 183 p. Tese (Doutorado em Ciências de Florestas Tropicais) - Instituto Nacional de Pesquisas da Amazônia, Universidade Federal do Amazonas, Manaus, 2010.

NEGRÓN-JUÁREZ, R., CHAMBERS, J., GUIMARÃES, G., ZENG, H., RAUPP, C.F., MARRA, D.; RIBEIRO, G.H.P., SAATCHI, S., NELSON, B., HIGUCHI, N., Widespread Amazon forest tree mortality from a single cross-basin squall line event. Geophysical Research Letters, v. 37, n. 16, p. 1-5, 2010.

OLIVEIRA, M. V. N.; BRAZ, E. M. Estudo da dinâmica da floresta manejada no projeto de manejo florestal comunitário do PC Pedro Peixoto na Amazônia Ocidental. Acta Amazonica, Manaus, v. 36, n. 2, p. 177-182, 2006.

SCHMID, S.; THÜRIG, E.; KAUFMANN, E.; LISCHKE, H.; BUGMANN, H. Effect of forest management on future carbon pools and fluxes: a model comparison. Forest Ecology and Management, Amsterdan, v. 237, p. 65-82, 2006.

SEEG BRASIL - SYSTEM FOR GREENHOUSE GAS EMISSIONS AND REMOVAL ESTIMATES. Emissões Totais. 2017. Disponível em http://seeg.eco.br/en/. Acesso em: 03 mar. 2017.

SEIDL, R.; RAMMER, W.; JÄGER, D., CURRIE, W. S.; LEXER, M. J. Assessing trade-offs between carbon sequestration and timber production within a framework of multi-purpose forestry in Austria. Forest Ecology and Management, Amsterdan, v. 248, n. 1-2, p. 64-79, 2007.

Sci. For., Piracicaba, v. 46, n. 119, p. 427-436, set. 2018 DOI: dx.doi.org/10.18671/scifor.v46n119.10 
SILVA, E. J. V. Dinâmica de florestas manejadas e sob exploração convencional na Amazônia Oriental. 2004. 171 p. Tese (Doutorado em Ciências da Engenharia Ambiental) - Escola de Engenharia de São Carlos, Universidade de São Paulo, São Carlos, 2004.

SILVA, J. N. M., CARVAlHO, J. O. P., LOPES, J. C. A., AlMEIDA, B. F., COSTA, D. H. M., OliVEIRA, L. C., VANCLAY, J. K. E SKOVSGAARD, J. P. Growth and yield of a tropical rain forest in the Brazilian Amazon 13 years after logging. Forest Ecology and Management, Amsterdam, v. 71, p. 267-274, 1995.

SILVA, J. N. M.; DE CARVALHO, J. O. P.; LOPES, J. C. A.; DE OLIVEIRA, R. P., DE OLIVEIRA, L. C. Growth and yield studies in the Tapajos region, Central Brazilian Amazon. Commonwealth Forestry Review, v. 75, n. 4, p. 325-329, 1996.

SILVA, R. P. Alometria, estoque e dinâmica da biomassa de florestas primárias e secundárias na região de Manaus (AM). 2007. 152 p. Tese (Doutorado em Ciências de Florestas Tropicais) - Instituto Nacional de Pesquisas da Amazônia, Universidade Federal do Amazonas, Manaus, 2007.

Recebido em 23/03/2017

Aceito em 13/11/2017 